\title{
HUBUNGAN PELAKSANAAN PEMBERIAN OBAT DENGAN PRINSIP DUA BELAS BENAR TERHADAP TINGKAT KEPUASAN PASIEN DI RUANG RAWAT INAP RSD MANGUSADA BADUNG
}

\author{
Ni Kadek Pande Eka Sudarminingsih ${ }^{1}$, I Made Dwie Pradnya Susilal, , A.A. Ngurah Nara \\ Kusuma ${ }^{l}$, Ni Made Risna Sumawati ${ }^{1}$ \\ STIKES Bina Usada Bali ${ }^{1}$ \\ e-mail: dwiepradnya@gmail.com*
}

\begin{abstract}
Nurses are the spearhead of services that greatly affect patient satisfaction as service users in the hospital. One of the nursing services that provided by nurses is administering drugs. The twelve correct principles of drug administration are the most current principles of medication, consisting of correct patient, correct drug, correct dose, correct method of administration, correct time, correct documentation, correct health education regarding medication, patient right to refuse, correct assessment, correct evaluation, correct reaction to food and correct reaction to other drugs. This study aimed to determine the correlation between the implementation of drug administration with twelve correct principles on the level of patients' satisfaction in the Inpatient Ward of Mangusada Badung General Hospital.This research was a quantitative study with observational methods and cross sectional design, the sample in this study were patients and the population of nurses in Mangusada Badung General Hospital according to the inclusion and exclusion criteria selected by purposive sampling of 58 patients and 58 nurses. The research was conducted for 1 month. Data were analyzed using nonparametric rho spearman test at a significance level of $\alpha 0.05$, $p$ value was $0.000<0.05$. It showed that there was a significant correlation between the implementation of drug administration with Twelve correct principles on the level of patients' satisfaction in the Inpatient Ward of Mangusada Badung General Hospital. It is expected that health workers, especially nurses, can apply the principles of correctness in administering drugs to increase patient satisfaction.
\end{abstract}

Keywords: drug administration, Twelve correct principles, patient satisfaction

\begin{abstract}
ABSTRAK
Perawat merupakan ujung tombak pelayanan yang sangat mempengaruhi kepuasan pasien sebagai pengguna layanan di rumah sakit. Salah satu pelayanan keperawatan yang sering dilakukan perawat adalah pemberian obat. Prinsip dua belas benar pemberian obat merupakan prinsip medikasi paling terkini, yang terdiri dari benar pasien, benar obat, benar dosis, benar cara pemberian, benar waktu, benar dokumentasi, benar pendidikan kesehatan perihal medikasi, hak pasien untuk menolak, benar pengkajian, benar evaluasi, benar reaksi terhadap makanan dan benar reaksi terhadap obat lain. Penelitian ini bertujuan untuk mengetahui hubungan pelaksanaan pemberian obat dengan prinsip dua belas benar terhadap tingkat kepuasan pasien di Ruang Rawat Inap RSD Mangusada Badung. Jenis penelitian adalah penelitian kuantitatif dengan metode observasional serta rancangan cross sectional, sampel dalam penelitian ini adalah pasien dan populasi perawat di RSD Mangusada sesuai dengan kriteria inklusi dan ekslusi dipilih dengan cara purposive sampling sejumlah 58 pasien dan 58 perawat. Penelitian dilaksanakan selama 1 bulan. Data dianalisis dengan uji nonparametric rho spearman pada tingkat kemaknaan $\alpha$ 0.05 , didapatkan nilai $\mathrm{p}$ sebesar $0.000<0.05$. Hal ini menunjukkan ada hubungan yang signifikan antara pelaksanaan pemberian obat dengan prinsip dua belas benar dengan tingkat kepuasan pasien di Ruang Rawat Inap RSD Mangusada Badung. Diharapkan tenaga kesehatan khususnya perawat dapat menerapkan prinsip dua belas benar dalam pemberian obat untuk meningkatkan kepuasan pasien.
\end{abstract}

Kata kunci: pemberian obat, prinsip dua belas benar, kepuasan pasien

\section{PENDAHULUAN}

Perawat merupakan ujung tombak pelayanan yang sangat mempengaruhi kepuasan pasien sebagai pengguna layanan di rumah sakit, sebab perawat berada mendampingi pasien selama 24 jam memberikan asuhan keperawatan (Nursalam, 2011). Salah satu dari pelayanan keperawatan yang diberikan perawat kepada pasien yang dirawat dirumah sakit adalah pemberian obat. Dalam memberikan pelayanan keperawatan, Standar Operasional Prosedur (SOP) sangat penting dan sangat membantu perawat untuk 
mencapai sebuah asuhan keperawatan yang berkualitas sehingga perawat harus mampu berpikir realistis tentang pentingnya evaluasi sistematis terhadap semua aspek asuhan keperawatan yang dilaksanakan, termasuk standar dalam pemberian obat (Basuki, 2018).

Permasalahan kesalahan pemberian obat atau yang dikenal dengan administrasi obat dari perawat kepada pasien sangat berisiko untuk terjadi. Oktarlina (2017) menyebutkan bahwa diperkirakan 44.000 98.000 pasien rawat inap di Amerika meninggal setiap tahun akibat kesalahan pengobatan. Penelitian di Australia pada tahun 2016 disebutkan bahwa medication error dikarenakan kesalahan peresepan ada 3-37\% dari kesalahan obat, persiapan obat 5-58\%, pemberian obat $72-75 \%$ dan dokumentasi $17-21 \%$, meskipun akurasi estimasi dipengaruhi oleh variabilitas yang besar dalam definisi dan metode pengukuran yang digunakan (Westbrook, 2016). Menurut penelitian yang dilakukan oleh Lestari (2014) di rumah sakit Mardi Rahayu Kudus didapatkan data $30 \%$ obat yang diberikan tidak didokumentasikan, $15 \%$ obat diberikan dengan cara yang tidak tepat, $23 \%$ obat diberikan pada waktu yang tidak tepat, $2 \%$ obat tidak diberikan, dan $12 \%$ obat diberikan dengan dosis yang tidak tepat.

Prinsip dua belas benar pemberian obat merupakan prinsip medikasi yang paling terkini, yang terdiri dari benar pasien, benar obat, benar dosis, benar cara pemberian, benar waktu, benar dokumentasi, benar pendidikan kesehatan perihal medikasi, hak pasien untuk menolak, benar pengkajian, benar evaluasi, benar reaksi terhadap makanan dan benar reaksi terhadap obat lain (Utami, 2015). Jika perawat bisa melaksanakan prinsip dua belas benar ini sesuai dengan standar yang ditetapkan maka akan dapat menunjang indikator kualitas suatu pelayanan keperawatan di rumah sakit, sehingga pasien akan merasa puas dengan pelayanan yang diberikan dan standar kepuasan pasien akan terpenuhi (Utami, 2015).

Kepuasan pasien merupakan salah satu hal penting yang harus diperhatikan dalam pelayanan kesehatan. Kepuasan adalah perasaan senang seseorang yang berasal dari perbandingan antara kesenangan terhadap aktivitas dan suatu produk dengan harapannya (Nursalam, 2011). Pada dasarnya setiap orang ingin mendapatkan pelayanan yang sebaik-baiknya pada pelayanan jasa yang mereka pilih. Kepuasan pasien adalah salah satu indikator kualitas pelayanan yang kita berikan (Fallis, 2013).

Peraturan Kementrian Kesehatan Republik Indonesia Tahun 2016 tentang Standar Pelayanan Minimal untuk kepuasan pasien yaitu diatas 95\% (Moeloek, 2016). Bila ditemukan pelayanan kesehatan dengan tingkat kepuasaan pasien berada dibawah 95\%, maka dianggap pelayanan kesehatan yang diberikan tidak memenuhi standar minimal atau tidak berkualitas. Berdasarkan hasil survey dari Humas RSUP Sanglah (2018) sebagai rumah sakit rujukan di Bali secara umum tingkat kepuasan pasien terhadap pelayanan RSUP Sanglah adalah 87,3\%. Sebagai rumah sakit tipe B di Bali angka kepuasan pasien BRSU Tabanan adalah 84,75\% (Laporan SPM BRSU Tabanan, 2018). Menurut laporan Komite Peningkatan Mutu dan Keselamatan Pasien RSD Mangusada Kabupaten Badung (2018) diketahui bahwa telah terjadinya penurunan angka kepuasan masyarakat yaitu $80,81 \%$. Berdasarkan data tersebut dapat disimpulkan bahwa angka kepuasaan pasien masih tergolong rendah jika mengacu pada Peraturan Kementrian Kesehatan Republik Indonesia Tahun 2016 tentang Standar Pelayanan Minimal untuk kepuasan pasien, sehingga kepuasaan pasien menjadi salah satu permasalahan di rumah sakit khususnya di RSD Mangusada Badung.

Menurut Hilmawan (2014) dalam penelitiannya yang berjudul hubungan antara penerapan SOP pemberian obat prinsip enam benar dengan tingkat kepuasan pasien di RSUD Ungaran, menunjukkan adanya hubungan yang signifikan antara penerapan SOP pemberian obat prinsip enam benar terhadap tingkat kepuasan pasien. Penelitian yang dilakukan oleh Putri (2018) tentang hubungan pemberian informasi obat oral dengan kepuasan pasien di Ruang Rawat Inap Bakung RSUD Panembahan Senopati Bantul Yogyakarta juga menemukan bahwa adanya hubungan yang signifikan antara pemberian informasi obat oral dengan kepuasan pasien di Ruang Rawat Inap Bakung RSUD Panembahan Senopati Bantul Yogyakarta.

Sebagai satu-satunya rumah sakit pemerintah di Kabupaten Badung, RSD Mangusada Badung selalu berupaya menjaga mutu pelayanan dan kepuasan pasien, salah satunya dengan selalu bekerja sesuai dengan SOP yang telah ditetapkan khususnya dalam pemberian obat. Setelah dilakukan studi pendahuluan terhadap pemberian obat yang dilaksanakan di Ruang Paviliun Lantai 3 RSD Mangusada Badung, dari tanggal 10 - 15 Maret 2020, diketahui bahwa dari 10 perawat yang dilakukan observasi dalam pemberian obat kepada pasien hanya $40 \%$ yang melakukan pemberian obat dengan prinsip dua belas benar, $10 \%$ obat diberikan pada waktu yang tidak tepat, $20 \%$ tidak melakukan pemantauan dan pemeriksaan efek kerja obat yang telah diberikan dan $30 \%$ tidak memberikan informasi kepada pasien terkait obat yang diberikan. Untuk mengatasi permasalahan ini sebenarnya pihak manajemen RSD Mangusada Badung sudah melakukan upaya seperti sosialisasi dan monitoring evaluasi pada perawat untuk melaksanakan pemberian obat dengan prinsip dua belas benar, namun menurut keterangan dari Kepala Rawat Inap RSD Mangusada Badung menyatakan masih banyak stafnya yang belum melaksanakan pemberian obat dengan prinsip dua belas benar. Berdasarkan hasil observasi juga ditemukan bahwa setiap perawat yang melaksanakan prinsip dua belas benar pemberian obat saat memberikan medikasi ke pasien, menyebabkan pasien menyatakan respon positif seperti ungkapan terima kasih, apresiasi sudah dijelaskan dengan lengkap serta menunjukkan tingkat penerimaan yang lebih baik dari 


\section{Vol. 16 No.2 Mei - Agustus 2021}

pada yang tidak dilakukan standar pemberian obat dengan prinsip dua belas benar.

Berdasarkan latar belakang masalah di atas maka penulis tertarik melaksanakan penelitian yang lebih mendalam terkait hubungan pelaksanaan pemberian obat dengan prinsip dua belas benar terhadap tingkat kepuasan pasien di Ruang Rawat Inap RSD Mangusada Badung tahun 2020.

\section{METODE}

Jenis penelitian adalah penelitian kuantitatif dengan metode observasional serta rancangan cross sectional, sampel dalam penelitian ini adalah pasien dan populasi perawat di RSD Mangusada sesuai dengan kriteria inklusi dan ekslusi dipilih dengan cara purposive sampling sejumlah 58 pasien dan 58 perawat. Penelitian dilaksanakan selama 1 bulan. Data dianalisis dengan uji nonparametric rho spearman pada tingkat kemaknaan $\alpha 0.05$.

HASIL

\section{Karakteristik Responden}

Tabel 1

Distribusi Frekuensi Karakteristik Responden

\begin{tabular}{|c|c|c|}
\hline $\begin{array}{c}\text { Karakteristik } \\
\text { Responden Pasien } \\
\end{array}$ & $\mathbf{f}$ & $\%$ \\
\hline \multicolumn{3}{|l|}{ Usia (th) } \\
\hline $22-25$ & 12 & 20.7 \\
\hline $26-35$ & 21 & 36.1 \\
\hline $36-45$ & 11 & 19.0 \\
\hline $46-55$ & 7 & 12.1 \\
\hline$>55$ & 7 & 12.1 \\
\hline \multicolumn{3}{|l|}{ Jenis Kelamin } \\
\hline Laki-laki & 46.6 & 27 \\
\hline Perempuan & 53.4 & 31 \\
\hline \multicolumn{3}{|l|}{ Pendidikan } \\
\hline SMP & 5 & 8.6 \\
\hline SMA & 36 & 62.1 \\
\hline Diploma & 7 & 12.1 \\
\hline Sarjana & 10 & 17.2 \\
\hline $\begin{array}{c}\text { Karakteristik } \\
\text { Responden Perawat }\end{array}$ & $\mathbf{f}$ & $\%$ \\
\hline \multicolumn{3}{|l|}{ Usia (th) } \\
\hline $22-25$ & 10 & 17.2 \\
\hline $26-35$ & 40 & 69.0 \\
\hline $36-45$ & 8 & 13.8 \\
\hline
\end{tabular}

Jenis Kelamin

\begin{tabular}{ccc}
\hline Laki-laki & 13 & 22.4 \\
Perempuan & 45 & 77.6 \\
\hline Pendidikan & & \\
\hline Diploma & 25 & 43.1 \\
Sarjana & 33 & 56.9 \\
\hline
\end{tabular}

Berdasarkan di atas dapat dilihat bahwa, dari 58 perawat dan pasien yang dijadikan sebagai responden paling banyak pasien memiliki rentang usia $26-35$ tahun yaitu sebanyak 21 (36.1\%) reponden, sebagian besar berjenis kelamin perempuan yaitu sebanyak 31 (53.4\%) reponden dan berpendidikan SMA yaitu sebanyak $36(62.1 \%)$ reponden. Pada responden perawat sebagian besar memiliki rentang usia $26-35$ tahun yaitu sebanyak $40(69.0 \%)$ reponden, berjenis kelamin perempuan yaitu sebanyak 45 (77.6\%) reponden dan berpendidikan sarjana yaitu sebanyak 33 $(56.9 \%)$ reponden.

Pelaksanaan Pemberian Obat dengan Prinsip Dua Belas Benar di Ruang Rawat Inap RSD Mangusada Badung

Tabel 2

Pelaksanaan Pemberian Obat dengan Prinsip Dua Belas Benar

\begin{tabular}{ccc}
\hline $\begin{array}{c}\text { Pelaksanaan Prinsip } \\
\text { 12 Benar }\end{array}$ & F & \% \\
\hline Lengkap & 42 & 72.4 \\
Tidak lengkap & 16 & 27.6 \\
\hline Total & 58 & 100 \\
\hline
\end{tabular}

Berdasarkan tabel di atas diketahui sebagian besar pelaksanaan prinsip 12 benar dikategorikan dilaksanakan dengan lengkap yaitu oleh 42 (72.4\%) reponden.

Tingkat Kepuasan Pasien di Ruang Rawat Inap RSD Mangusada Badung

Tabel 3

Tingkat Kepuasan Pasien

\begin{tabular}{|c|c|c|}
\hline Kepuasan & $\mathbf{F}$ & $\%$ \\
\hline Puas & 44 & 75.9 \\
\hline Cukup Puas & 14 & 24.1 \\
\hline Total & 58 & 100 \\
\hline
\end{tabular}

Berdasarkan tabel di atas diketahui sebagian besar responden dikategorikan puas dengan pelayanan yang diberikan di Ruang Rawat Inap RSD Mangusada Badung yaitu sebanyak 44 (75.9\%) reponden 
Hubungan Pelaksanaan Pemberian Obat dengan Prinsip Dua Belas Benar Terhadap Tingkat Kepuasan Pasien di Ruang Rawat Inap RSD Mangusada Badung

Tabel 4

Pengaruh Gerakan Satu Rumah Satu Jumantik

\begin{tabular}{|c|c|c|c|c|}
\hline \multicolumn{5}{|c|}{ Correlations } \\
\hline & & & $\begin{array}{c}\text { Prinsip } 12 \\
\text { Benar }\end{array}$ & $\begin{array}{c}\text { Kepuasan } \\
\text { Pasien }\end{array}$ \\
\hline \multirow{6}{*}{$\begin{array}{l}\text { Spear } \\
\text { man's } \\
\text { rho }\end{array}$} & \multirow{3}{*}{$\begin{array}{l}\text { Prinsip } 12 \\
\text { Benar }\end{array}$} & $\mathrm{r}$ & 1.000 & $.463^{* *}$ \\
\hline & & $\begin{array}{l}p \\
\text { value }\end{array}$ & . & .000. \\
\hline & & $\mathrm{N}$ & 58 & 58 \\
\hline & \multirow{3}{*}{$\begin{array}{l}\text { Kepuasan } \\
\text { Pasien }\end{array}$} & $\mathrm{r}$ & $.463^{* *}$ & 1.000 \\
\hline & & $\begin{array}{l}p \\
\text { value }\end{array}$ & .000 & \\
\hline & & $\mathrm{N}$ & 58 & 58 \\
\hline
\end{tabular}

Berdasarkan table diatas dapat dilihat bahwa, nilai signifikansi yang diperoleh 0,000 sehingga $p$ value $<0,05$. Hal ini menyatakan ada hubungan yang signifikan antara pelaksanaan pemberian obat dengan prinsip dua belas benar dengan tingkat kepuasan pasien di Ruang Rawat Inap RSD Mangusada Badung. Nilai koefisien korelasi pada variable ini 0.463 menandakan hubungan yang cukup antara kedua variabel (Sugiyono, 2016). Mengarah ke arah korelasi positif, dapat dimaknai semakin lengkap pelaksanaan pemberian obat dengan prinsip dua belas benar maka semakin tinggi tingkat kepuasan pasien di Ruang Rawat Inap RSD Mangusada Badung.

\section{PEMBAHASAN}

Berdasarkan hasil yang didapat dalam penelitian ini salah satu faktor yang dapat memengaruhi kepuasan pasien adalah pelaksanaan pemberian obat dengan prinsip 12 benar yang dapat dilakukan dengan baik oleh perawat di Ruang Rawat Inap RSD Mangusada Badung. Melalui pelaksanaan pemberian obat dengan prinsip 12 benar yang baik membuat pasien menyatakan respon positif seperti ungkapan terima kasih, apresiasi sudah dijelaskan dengan lengkap serta menunjukkan tingkat penerimaan yang lebih baik dari pada yang tidak dilakukan standar pemberian obat dengan prinsip dua belas benar.

Hal ini juga dibuktikan dengan data crosstabulation yang didatapat dalam penelitian ini dimana dari 42 responden yang diberikan obat dengan prinsip 12 benar sebagian besar responden dikategorikan puas yaitu sebanyak $37 \quad(88.1 \%)$ responden, sedangkan dari 16 responden yang tidak diberikan obat dengan prinsip 12 benar sebagian besar responden dikategorikan cukup puas yaitu sebanyak 9 $(56.2 \%)$ responden.

Hasil ini tidak terlepas dari budaya kerja di RSD Mangusada Badung yang selalu menuntut pegawainya khususnya perawat untuk selalu bekerja sesuai dengan SOP. Perawat di RSD Mangusada Badung juga selalu mendapatkan dan diwajibkan untuk mengikuti training secara berkala yang berkaitan dengan peningkatan kualitas pelayanan salah satunya seperti pelaksanaan pemberian obat dengan prinsip 12 benar mengingat pemberian obat merupakan salah satu kegiatan pelayanan keperawatan yang sering dilakukan perawat kepada pasien yang dirawat dirumah sakit.

\section{KESIMPULAN}

Terdapat hubungan yang signifikan antara pelaksanaan pemberian obat dengan prinsip dua belas benar dengan tingkat kepuasan pasien di Ruang Rawat Inap RSD Mangusada Badung. Diharapkan tenaga kesehatan khususnya perawat dapat menerapkan prinsip dua belas benar dalam pemberian obat untuk meningkatkan kepuasan pasien.

\section{DAFTAR PUSTAKA}

1. Astuti, P. P. (2017). Hubungan Mutu Pelayanan Keperawatan dengan Kepuasan Pasien di RS PKU Muhammadiyah Bantul.

2. Basuki, D. (2018). Buku Ajar Manajemen Keperawatan untuk Mahasiswa dan Praktisi. In Buku Ajar Manajemen Keperawatan untuk Mahasiswa dan Praktisi.

3. Depkes RI. (2014). Permenkes No 30 Tahun 2014. Implementation

Science. https://doi.org/10.4324/9781315853178

4. Fallis, A. . (2013). Penjaminan Mutu Pelayanan Kesehatan dan Akseptabilitasnya. Jakarta: Penerbit Erlangga. https://doi.org/10.1017/CBO9781107415324.004

5. Harmiady, R. (2014). Faktor-faktor yang Berhubungan dengan Pelaksanaan Prinsip 6 Benar dalam Pemberian Obat oleh Perawat Pelaksana di Ruang Interna dan Bedah Rumah Sakit Haji Makassar. Jurnal Ilmiah Kesehatan. Diagnosis, 5 (4), 659-663.

6. Hilmawan, F. A. (2014). Hubungan Antara Penerapan Standart Operational Procedure (SOP) Pemberian Obat Prinsip Enam Benar Dengan Tingkat Kepuasan Pasien Di RSUD Ungaran. Jurnal Ilmu Keperawatan Dan Kebidanan, 1-10. Retrieved from http://ejournal.stikestelogorejo.ac.id/index.php/ilm ukeperawatan/article/view/266/291 


\section{Vol. 16 No.2 Mei - Agustus 2021}

7. Kamil, H. (2018). Handover dalam Pelayanan Keperawatan. Idea Nursing Journal, 4(2), 144152.

8. Katzung, B. G. (2012). Farmakologi Dasar dan Klinik Edisi 10. In Farmakologi Dasar dan Klinik Edisi 10.

9. Kemenkes RI. (2011). Modul Penggunaan Obat Rasional. Kemenkes RI.

10. Koesmiati, Sutriningsih, A., \& Rosdiana, Y. (2016). Hubungan Timbang Terima dengan Kepuasan Pasien di Ruang Rawat Inap RS Panti Waluya Sawahan Malang. Journal Nursing News, 1(1),

153-161. https://doi.org/10.1021/BC049898Y

11. Komite Peningkatan Mutu dan Keselamatan Pasien RSD Kabupaten Badung Mangusada. (2018). Laporan Komite Peningkatan Mutu dan Keselamatan Pasien RSD Kabupaten Badung Mangusada Tahun 2018. 15(4), 2046-2069. https://doi.org/10.1109/COMST.2015.2457491

12. Lestari, Y. N. (2014). Pengalamam Perawat Dalam Menerapkan Prinsip Enam Benar Dalam Pemberian Obat di Ruang Rawat Inap Rumah Sakit Mardi Rahayu Kudus.

13. Mawaliya, W. (2015). Analisis Tingkat Kepuasan Pasien Rawat Jalan Terhadap Kualitas Pelayanan Informasi Obat di Instalasi Farmasi Rumah Sakit Ortopedi Surakarta. Ilmiah Kesehatan, (April), 28 59.

14. Nasution, M. I. (2015). Penerapan 12 Benar Obat Sebagai Bentuk Realisasi Mendasar Sasaran Keselamatan Pasien. Jurnal Kesehatan Global, 2.

15. Notoadmojo, S. (2018). Metodelogi Penelitian Kesehaan. Indonesian Jourmal On Medical Science. https://doi.org/S0887899401003605 [pii]

16. Notoatmodjo, S. (2012). Metodologi Penelitian Ilmu Keperawatan. In Jakarta: Salemba Merdeka.

17. Nur, S. A. (2016). Perbedaan Kepuasan Pasien mengenai Metode Serah Terima Pasien Dengan Tradisional dan Bedside Handover.

18. Nursalam. (2011a). Konsep dan Penerapan Metodelogi Penelitian Ilmu Keperawatan: Pedoman Skripsi, TNursalam. (2011). Konsep dan Penerapan Metodelogi Penelitian Ilmu Keperawatan: Pedoman Skripsi, Tesis, dan Instrumen Keperawatan (2nd ed.). Jakarta: Salemba Medika.esis, dan In (2nd ed.). Jakarta: Salemba Medika.

19. Nursalam. (2011b). Manajemen Keperawatan Aplikasi dalam Praktik Keperawatan Profesional
Edisi 3. Salemba Medika. https://doi.org/10.1001/archinte.165.22.2659

20. Nursalam. (2015). Manajemen Keperawatan Aplikasi dalam Praktik Keperawatan Profesional (4th ed.). jakarta: Salemba Medika.

21. Nursalam. (2017a). Metodologi Penelitian Ilmu Keperawatan: Pendekatan Praktis. Metodologi Penelitian Ilmu Keperawatan: Pendekatan Praktis.

22. Nursalam. (2017b). Metodologi Penelitian Ilmu Keperawatan. In Salemba Medika.

23. Oktarlina. (2017). Kejadian Medication Error pada Fase Prescribing di Poliklinik Pasein Rawat Jalan Rumah Sakit Daerah Mayjend HM Ryacudu Kota Bumi. Fakultas Kedokteran Universitas Lampung, 1(3), 540-545.

24. Potter, P. (2008). Buku ajar fundamental keperawatan: konsep, proses, dan praktik. In Jakarta: EGC. https://doi.org/IOS3107-49534

25. Potter, P. A., Perry, A. G., Stockert, P. A., \& Hall, A. M. (2013). Fundamental of Nursing Eight Edition. In Elsevier. https://doi.org/10.1109/ISCA.2016.31

26. Putri, I. R. R. (2018). Hubungan Pemberian Informasi Obat Oral dengan Kepuasan Pasien di Ruang Bakung RSUD Panembahan Senopati Bantul. Indonesian Journal of Hospital Administration, 4(1), 57-66.

27. Sabarguna. (2013). Pemasaran Pelayanan Rumah Sakit. Jakarta.

28. Setiadi. (2007). Konsep Dan Penulisan Riset Keperawatan. ;2007. In Graha Ilmu : Yogyakarta. https://doi.org/10.1186/1471-2105-8-89

29. Sugiyono. (2016). Metodologi Penelitian Kuantitatif, Kualitatif, dan R\&D. In CV Alfabeta. https://doi.org/https://doi.org/10.3929/ethz-b000238666

30. Tiara, \& Lestari, A. (2013). Perilaku Caring Perawat Dalam Meningkatkan Kepuasan Pasien rawat Inap. Jurnal Keperawatan.

31. Utami, R. (2015). Hubungan Motivasi Perawat dengan Pelaksanaan Prinsip 12 Benar dalam Pemberian Obat di Ruang Rawat Inap RSU dr . H . Koesnadi Bondowoso Implementation of 12 Principles of Right in Medicine Giving in Inpatient Wards of dr. H . Koesnadi Hospital In Bondowos. E-Jurnal Pustaka Kesehatan, 3(3), 457-463.

32. Westbrook, J. I. (2016). Stepped-wedge cluster randomised controlled trial to assess the effectiveness of an electronic medication management system to reduce medication errors, 
adverse drug events and average length of stay at two paediatric hospitals: A study protocol. $B M J$
Open,

$6(10)$

$1-11$. 